Пайдаланылван ддебиеттер тізімі:

1 Нұралиева А.Ж.Қазақ ойшылдары мен агартушы-педагогтарының еңфектеріндегі халық музыка шыгармамылыгының педагогикалық мүмкіндіктері тураль идеялар. http://rusnauka.com/27 NII 2010/Pedagogica/71930.doc.htm

2 Қазақ ддебиеті. Энииклопедиялық анықтамалық. - Алматы: «Аруна Ltd.» ЖШС, 2010-573б.

3 Тойшыбайұльы A. Abai.kz. 11 шілде, 2014.

4 Орыс тілінен аударван Қоңыратбаев Ә., Байділдаев М. Қорқыт ата кітабы. Овыздардың батырлық жырлары: Эпос-Алматы: Жазушы, 1986. -128 б.

5 Аль - Фараби. Избранные трактаты. /Перевод с арабского. - Алматы: Ғыльым, 1994.-337с.

6 Баласавұн Ж. Құтты білік./ Көне түркі тілінен аударван және алвы сөзі мен түсініктерін жазван А.Егеубаев. - Алматы: Жазушы, 1986. -613 б.

7 Алтынсарин Ы. Таңдамалы шывармалары. -Алматы: Fылым, 1994.- 2886.

8 Валиханов Ч. Ч. Собрание соч. в 5 томах. - Алма-Ата: Наука, 1985-528c.

9 Құнанбаев А. Шызармалары (екі томдық). - Алматы: Жазушы. 1977-455б.

10 Торайхыров С. Екі томдық шызармалар жинавы. -Алматы: Ғыльым, 1993. - T.1. -280 б.

References:

1. Nüralieva A.J.Qazaq oişyldary men ağartuşy-pedagogtarynyñ eñbekterındegl halyq muzyka şyğarmaşylyğynyñ pedagogikalyq mümkındikterl turaly ideialar. http://rusnauka.com/27_NII_2010/Pedagogica/71930.doc.htm

2. Qazaq ädebietı. Ensiklopedialyq anyqtamalyq. - Almaty: «Aruna Ltd.» JŞS, 2010-573b.

3. Toişybaiūly A. Abai.kz. 11 şılde, 2014.

4. Orys tılınen audarğan Qoñyratbaev Ä., Baidlldaev M. Qorqyt ata kitaby. Oğyzdardyñ batyrlyq jyrlary: Epos - Almaty: Jazuşy, 1986. -128 b.

5. Äl-Farabi. İzbrannye traktaty. /Perevod s arabskogo. - Almaty: Ğylym, 1994.-337s.

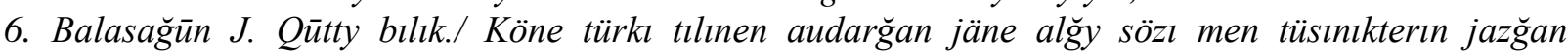
A.Egeubaev. - Almaty: Jazuşy, 1986. -613 b.

7. Altynsarin Y. Tañdamaly şyğarmalary. -Almaty: Ğylym, 1994.- 288 b.

8. Valihanov Ch. Ch. Sobranie soch. $v 5$ tomah. - Alma-Ata: Nauka, 1985-528s.

9. Qünanbaev A. Şyğarmalary (ekı tomdyq). - Almaty: Jazuşy. 1977-455b.

10. Toraiğyrov S. Ekn tomdyq şy̆garmalar jinăgy. -Almaty: Ğylym, 1993. - T.1. -280 b.

МРНТИ 16.31.51

https://doi.org/10.51889/2020-2.1728-7804.16

\author{
Kulakhmetova M., ${ }^{1}$ Tasbolatov $O{ }^{2}$ \\ ${ }^{1,2}$ Pavlodar State Pedagogical University, \\ Pavlodar, Kazakhstan
}

\title{
SOCIOCULTURAL ASPECT AS A COMPONENT OF FOREIGN LANGUAGE COMMUNICATIVE COMPETENCE
}

\begin{abstract}
The article considers the relevance and importance of the formation of sociocultural competence in modern educational practice. It is shown that in order to create a more tolerant and cultural oriented society, as well as successful socialization of young people, high-school's foreign language teachers need to create a positive ethno-linguistic and ethno-psychological cultural atmosphere in the classroom, that leads young minds to tolerant and healthy behavior towards other cultures and nations, which is one of the most important aspects of education in the context of modern and comprehensive globalization. The formation of sociocultural competence as a component of the communicative competence of schoolchildren is considered and examples of its successful formation in high school with in-depth study of the English language are given.
\end{abstract}

Keywords:communication, competence, culture, component, personality

$$
\text { Кулахметова М., }{ }^{1} \text { Тасболатов } \mathrm{O}^{2}
$$




\author{
${ }^{1,2}$ Павлодар мемлекеттік педагогикалық университеті, \\ Павлодар, Қазақстан
}

\title{
ШЕТ ТІЛІНІҢ КОММУНИКАТИВТІ ҚҰЗІРЕТТІЛІГІНІҢ БӨЛІГІ РЕТІНДЕГІ ӘЛЕУМЕТТІК-МӘДЕНИ АСПЕКТ
}

\begin{abstract}
Ан̆датпа
Мақалада заманауи білім тәжірибесіндегі әлеуметтік-мәдени құзыреттіліктерді қалыптастырудың мәні мен өзектілігі қарастырылады. Толерантты әрі мәдени қоғам құру үшін, сондай-ақ жастардың табысты әлеуметтенуі үшін жоғары сыныптарда сабақ беретін оқытушылар сыныпта этнолингвистикалық және этнопсихологиялық мәдени ахуал тудыру қажет екені көрсетілген, бұл өз кезегінде жеткіншектерді өзге ұлттар мен олардың мәдениетіне деген оң көзқарасқа тәрбиелейді. Бұл қазіргі жаһандану дәуірінде білім берудің маңызды аспектісі болып табылады. Әлеуметтік-мәдени құзыреттіліктің қалыптасуын оқушылардың коммуникативті құзыреттілігінің бөлігі ретінде қарайды және оның ағылшын тілін тереңдетіп оқытатын жоғары мектеп жағдайында табысты қалыптасуға мысал келтіреді.
\end{abstract}

Түйін сөздер: құзіреттілік, коммуникация, мәдениет, бөлік бөлшек, тұлға

$$
\text { Кулахметова М., }{ }^{1} \text { Тасболатов } \mathrm{O}^{2}
$$

1,2 Павлодарский государственный педагогический университет, Павлодар, Казахстан

\section{СОЦИОКУЛЬТУРНЫЙ АСПЕКТ КАК КОМПОНЕНТ ИНОЯЗЫЧНОЙ КОММУНИКАТИВНОЙ КОМПЕТЕНЦИИ}

\section{Аннотация}

Статья рассматривает актуальность и значимость формирования социокультурной компетенции в современной образовательной практике. Показано, что для создания более толерантного и культурного общества, а также успешной социализации молодых людей, преподавателям иностранных языков старших классов является необходимым создание положительной этнолингвистической и этнопсихологической культурной атмосферы в классе, что в свою очередь ведёт молодые умы к терпимому и здравому поведению по отношению к другим культурам и нациям, что является важнейшим аспектом образования в условиях современной и всеобъемлющей глобализации. Рассматривается формирование социокультурной компетенции как компонент коммуникативной компетенции школьников и приводит примеры её успешного формирования в условиях старшей школы с углубленным изучением английского языка.

Ключевые слова:коммуникация,компетенция, культура, компонент, личность

Introduction. Integration and processes associated with internationalization in various areas of human life, which take place within the professional and personal contacts of members of different cultural communities, the features of the socio-economic situation in the modern world, as well as the increasing processes caused by globalization in such areas as education, science, culture and others, led to the desire of Kazakhstan to join the world community, which resulted in the need for high-quality training of specialists of various professions, who would have the skills of oral and written foreign language communication. The priority and importance of this goal is fixed in the current educational program of updated content. The goals of teaching foreign languages identified in this program are considered to be a key factor that determines the selection of content, methods, means and techniques for achieving the goals specified in them. It is obvious that the purpose of learning a foreign language is understood as a multidimensional concept, which includes a number of tasks for the formation of the student's personality, able and willing to participate in communication, and the emergence of the student's key characteristics of the secondary language personality, which would make up a complex integrative whole, reaching the cross-cultural competence.

Methodology.Speech etiquette of a foreign language is important for the education of the personality as a whole. You can learn a lot by studying their conversational etiquette. Therefore, much attention is paid to the study of cliches, stable colloquial phrases, phraseological turns [1, 64]. Learning a language involves not 
only a dry study of grammar rules, but also the knowledge of cultural aspects of people's lives, the culture is being studied intensively today. That is why the formation of socio-cultural competence is such an important aspect of the dialogue. In the European standard for learning foreign languages, sociocultural competence is defined as an aspect of communication ability that relates to those special features of society and culture that are expressed in the communicative behavior of members of society [2, 156]. Under the socio-cultural competence, a number of researchers understand the knowledge of the socio-cultural context of the language being studied and the experience of using this knowledge in the process of communication. In this study, we offer a working definition as: sociocultural competence is the ability to organize socio-cultural knowledge in intercultural communication.

The sociocultural component of the content of teaching foreign languages has great potential in terms of including students in the dialogue of cultures, exploring the achievements of the national culture in the development of universal culture, because it is included in the content of the national culture. So, for example, in the lessons on linguistic studies, students get acquainted with the geographical position of Great Britain, its social structure, study the culture of English-speaking countries $[3,86]$. There are three levels of sociocultural competence: cognitive, behavioral, and emotional-evaluative, that is, each student of a new language acquires the socio-cultural content gradually and can communicate in the language being studied with varying degrees of adequacy to the conditions of intercultural communication. Selection of language and culture proficiency levels is possible not only on the basis of the degree of formation of certain skills, but also from the point of view of the content of assimilation:

- cognitive level, which implies knowledge of the peculiarities of the language being studied and the culture of its speakers;

- behavioral level that provides knowledge of behavior models of native speakers of the studied language, knowledge of speech and non-speech behavior skills;

- emotional and evaluative level that provides awareness and evaluation of their own emotional reactions to the peculiarities of the culture of the people whose language is being studied; identification of similarities and differences between the phenomena of other and native culture.

When identifying the structure of the socio-cultural component of language learning, it is necessary to proceed from the structure of the cultural phenomenon itself. Culture in its broadest sense is the only source from which the content of education as a whole is drawn, since education always performs one general function - the transmission to the younger generation of the level of culture achieved by this society for its preservation and further development. Outside of culture, there is nothing that can be included in the content of education, and at the same time, the content of education must include all elements of culture in order to fully develop the individual.

Culture includes knowledge, norms of behavior of community members and a system of values, which, no doubt, should be reflected in the structure of the socio-cultural component of the content of language training, which should include:

- socio-cultural knowledge formed as a result of assimilation of information and information about the facts of the culture of the country of the studied language;

- skills and abilities that reflect national behavior and speech etiquette;

- relationships that are formed on the basis of a value system.

For effective formation of students' socio-cultural competence in the course of teaching a foreign language, it is necessary to focus sufficient attention on such specific pedagogical principles as: the principle of consistency, clarity, consciousness and creative activity, practical orientation of training, taking into account individual characteristics, educational training. The principles are also highlighted and considered separately:

1) a native language teacher who considers the need for a high level of knowledge of their own language;

2) communicative orientation of training;

3) the principle of intercultural interaction;

4) the principle of learning in the context of cultural dialogue.

Developed in Kazakhstan's methodological science, the methodology of linguoculturology of modern foreign language education is put forward as the goal of education in the formation of "the subject of intercultural communication" and "language and culture are an integral part of the process of cognition" [4. 201]. The "Foreign language" discipline in the school assumes compliance with all the above-mentioned principles within the updated educational program. The above-mentioned principle of creative activity meets 
the key objectives of the foreign language learning goals, since by implementing this approach, it is possible to activate the educational activity of each student within the educational process, especially if they are involved in various activities or communicative situations through the use of a problematic communicative topic, role-playing game. It is obvious that the main emphasis placed today on the teaching process itself and its intellectual, emotional and speech components, the combination of which provided the necessary conditions for effective learning of a foreign language. Let us consider in more detail the intellectual activity that was supposed to be achieved through the formulation of problematic issues, as well as reading meaningful texts and their interpretation, and independent work of students.

J. Banks describes culture as "the values, symbols, interpretations and perspectives that distinguish one nation from another in modernized societies"[5.360].

Emotional activity appeared when students enjoyed the process of completing tasks, liked the language being studied and the process of studying it is organized by the teacher. To do this, the teacher needs to use additional tools throughout the training period to stimulate and warm up the student's interest in the discipline. As for speech activity, it occurred during oral communication and was largely determined by the intellectual and emotional activity that stimulates it. In order to increase the effectiveness of the most effective involvement of each student in educational activities, we used various options for working in the classroom: working as a choir, working in groups, collective work, individual work. Firth adds "throughout the growth period, we gradually become involved in our social organization, and the main condition and means of this association is to learn to say what the other person expects from us in the given circumstances" [6. 59]. The model of "dialogue of cultures" proposed by V. V. Safonova served as the basis. Russian science also contains a number of theories and methods for teaching language competence and its structure. Thus, V. V. Safonova offers the following model of the structure of language competence. The following elements are highlighted as part of the competence:

1) language information about the key rules of lexical and grammatical design of phrases and superphrasal unities in the studied types of speech works (RP), pronouncing rules for the design of foreignlanguage music, intonation and syntactic rules for the construction of studied phrases, super-phrasal unities, discourse, general and specific ways of expressing universal categories in native and foreign languages;

2) language skills-recognition of lexically and grammatically acceptable utterances in a foreign language, decoding of language concepts and representations in speech works in a foreign language, figurative and schematic representation of language information about the rules of construction and design of phrases and super-phrasal units in a foreign language, phonetic, lexical-grammatical, intonation-syntactic design of statements in accordance with literary norms;

3) language skills for linguistic observation and generalization of its results in the form of rules (verbal and figurative-schematic) and language algorithms.

Describing the current situation in the educational field, attention is focused on the fact that the cultural space, modeled with the help of current educational literature, reflects the following characteristics: sufficiently closed, in particular, the culture of the establishment is modeled, and not the variability of culture, lifestyles in a particular society; - involuntary manipulation of students' ideas about the cultural achievements of peoples; - excessive dominance of pragmatic orientations, for example, Culture with a capital letter is expelled from modern textbooks (there are no excerpts from classical works, information about masterpieces of music, painting, technology, information about outstanding cultural figures, etc.); lack of any orientation and support for the native culture, as a result of which it leaves foreign language communication. The last of the mentioned shortcomings causes the greatest damage when teaching intercultural communication, because in a situation of intercultural interaction, you constantly have to not only interpret someone else's culture, but also represent your own.

It is important to note that digital students are in a state of constant stimulation and development of the nervous system using technology. These are natural producers or consumers of information. Solving a problem is a skill that is natural to them and can be deeply promoted with proper participation in their training. This comes from the implementation of useful projects and significant tasks that pose them with tasks that must be overcome creatively, which ultimately stimulates the development of sociocultural competence.

Ask any student what they like to create, and you will get many different answers. They are constantly looking for ways to express themselves and their uniqueness. Through social networks, they demonstrate this creative advantage and receive constant and instant feedback from their colleagues. The same level of creative power is used when they encounter interesting problems and figure out how to meet them with 
ingenuity and foresight. That is why fluency in creativity is one of the basic skills for fluent communication in any language. It was this approach that inspired us to this experiment. Let's dwell on the main reasons why it is the creative approach that we consider most relevant today.

Creativity is a vital outlet that inspires them to see who they are and what they can do, and to realize what they can achieve. Fundamentally, this side of any student is allowed to shine in their learning.

Students need the ability to think analytically, which includes the ability to compare, contrast, evaluate, synthesize and apply without instruction or control.

Analytical thinking means being able to use a higher level of Benjamin Bloom's digital taxonomy or higher order thinking skills.

Tasks that require linear thinking and routine cognitive work are increasingly outsourced. Therefore, it is important to guide students toward the ability to complete assignments using analytical thinking. This is important for their ability to succeed in life after class. Analytical thinking is an important part of what constitutes information fluency.

Analytical thinkers see data and information in different dimensions and from different angles. They are well versed in conceptualization, organization and classification, as well as in the synthesis of knowledge. These types of skills are invaluable because they allow older students to practically deal with social and cultural issues. This gives them the opportunity to make effective and informed decisions in their lives and relationships with society. It is easy to understand why critical and analytical thinking skills are important for success both in school and after graduation.

Students should have the ability to seamlessly collaborate in both physical and virtual spaces with real and virtual partners around the world.

Why it is important: digital students are social in nature. They write, publish, update, share, communicate and constantly create each other in technological environments. When they cannot do this at school, they become divorced and not attached to their learning. Communication and collaboration with others is important not only for their learning, but also for their mental and emotional health. This is a skill that teachers should use regularly with them.

Solving a problem is a skill that is naturally inherent in students and can be deeply promoted with proper participation in learning.

The workforce of the future (and even of our present day) is globalizing thanks to the Internet. Now it has become the norm to instantly and effectively communicate. Business partners and organizations are now located around the world, and yet they meet and work with each other every day. The ability to collaborate and communicate in these situations is of great cultural importance.

Teaching culture really raises cultural awareness, appreciation and acceptance of other cultures, as well as raising awareness of one's own culture. Due to the fact that language children pose themselves as a native speaker through role-playing games or the interaction of students with their native language, acting through participation in ethnographic interviews, language teachers open the doors for students who otherwise remain closed without studying the target culture. Creating a tolerant atmosphere in the classroom in which all cultures are glorified, and explicit teaching about the target culture allows the language teacher to influence the students' attitude to the target language and culture in a positive way.

Experiment. It is great to simulate an artificial situation in which children will be involved in the process of learning a foreign language. The experimental base was chosen Bilim - innovation lyceum boarding school for gifted youths of the city of Pavlodar.

Students of grade 7B were observed for 3 months studying culturally rich material. In practice, in artificial conditions created as part of their work - projects, they learned new interesting aspects of different cultures. As a result, the formation of their sociocultural and communicative competence has grown and a memo has been created that resembles the importance of respect for other cultures without forgetting your own.

Finally, organizations of older students who want to become competent and successful citizens who think about cooperation should ask themselves, given the potential problems, should they even cooperate? Is this an impossible goal? On the other hand, problems should not frighten anyone if it is possible to solve them with special efforts. There will be no unanimous agreement on all issues. This is normal because healthy differences can be productive and desirable. At the same time, there can be many ways to work together and experience the many rewards received by building the relationships necessary to complete the work. 
Guidelines for intercultural cooperation. Cultural issues about who we are and how we identify ourselves are at the heart of multicultural collaboration. In the course of practice, the main recommendations were highlighted when confronted with communication barriers that impede the development of intercultural activities:

1) It is necessary to correctly generalize other cultures and races, do not use these generalizations to stereotype, write off or simplify your ideas about another person. The best use of generalization is to add it to your repository of knowledge so that you better understand and value other, interesting, and multifaceted people.

2) Practice, practice, practice. This is the first rule, because it is because of this that we become better in intercultural communication.

3) Do not think that there is one right way to communicate. Continue to doubt your assumptions about the "right way" of communication. For example, think about your body language; poses that indicate susceptibility in one culture may indicate aggressiveness in another.

4) Do not think that communication failures occur because other people are on the wrong path. Look for ways to make communication work, not look for who should get the blame for the breakdown.

5) Listen actively and sympathetically. Try to put yourself in the place of another person, especially when the perception or ideas of another person are very different from your own. You may need to work at the edge of your own comfort zone.

6) Respect other people's decisions about whether they should communicate with you. Respect their opinions about what is happening around.

7) Stop, suspend the judgment and try to look at the situation from a different angle. For example, when you notice obstacles or difficulties in working with people, review your own beliefs or behavior that may be holding you back. Also, think about how others see your working relationships and decide how you can change your behavior to make them more comfortable. For example, you can talk or dress very formally or be more informal in dress and behavior, which can improve the situation.

8) Be prepared to discuss the past. Use this as an opportunity to develop understanding from the perspective of the "other". Recognition of historical events that have occurred. Be open to learn more about them. Honest recognition of the abuse and oppression that took place on the basis of cultural differences, vital to effective communication.

9) Know and remember about current imbalances. Be prepared to hear the perception of these imbalances from each other. You need to understand each other and work together.

Remember that cultural norms may not apply to the behavior of a particular person. We are all formed by many factors (ethnic origin, family, education, personalities) and are more complex than any cultural norm can assume. Check your interpretations if you are not sure what is meant.

For example, in order to be in good relations with all representatives of cultures in the class, we must learn traditions and values that are different from ours. We must understand that each of us has customs that may seem like strangers. For example, in Kazakhstan, residents tend to call friends and colleagues by name as a sign of friendliness. However, in many Japanese communities, respect is shown in the use of surnames. Some often start their meetings by sharing food before starting a business. For others, eating before work seems unproductive.

It is necessary to integrate aspects of different cultures into all our actions. Almost all events lend themselves to a multicultural approach, including: social events, sports, street fairs, talent shows, campaigns, neighborhood improvement projects, demonstrations and lobbying.

It is important to conduct events in mutually acceptable places. Organizers should go to the community to host events, and not expect the community to come to them. Often, an informal atmosphere helps people relax and get to know each other more easily. An example is an informal discussion of a film that was previously watched in a foreign language. It is rather difficult to consciously develop projects on which children from different cultures can work together. It's crucial to create mixed teams or small groups so that they get more collaboration experience.

To authorize the periodic use of groups or groups with the same culture as a way to assess the need for each group to strengthen its position and strengthen its own approach to working with a large group.

Conducting special events to inform everyone about various cultural issues (for example, forums, conferences, panels, organized dialogs). 
If your activity does not attract a diverse crowd, try holding special events designed specifically for different groups. Such events should be conducted and organized by representatives of these groups. Let your joint organization or community identify issues and events that they consider important.

Conducting work to reduce prejudice, such as diversity training or awareness-raising training for different cultures to change assumptions and attitudes among your members or community, has proven to be more difficult in practice than in theory. The use of qualified facilitators / trainers is a great help for the development of sociocultural competence, but it is not always an affordable means, and the teacher often does not have special qualities for holding such events, in particular stimulating and exciting the crowd, as well as motivating them to develop and participate in extracurricular activities caused a lot of problems with us. Such training could help our collaborative organization to assess differences and understand how to reduce insensitive behavior.

It is important to communicate and collaborate with other groups committed to the principles of multiculturalism, or those who fight discrimination / promote social justice.

Conclusion.In general, this study clearly showed that an approach based on studies of sociocultural competence is effective in motivating students to value cultural diversity.The construction of multicultural cooperation entails a change in the way of thinking, perception and communication of people. There is a difference between the recognition of cultural differences and the conscious inclusion of inclusive and antidiscrimination approaches in all aspects of the organization. Accepting cultural differences is not something separate from your problem-oriented work. It underlies the group's view of problems, possible solutions, as well as membership and working procedures. The structure, leadership and activities of the organization of work should reflect different perspectives, styles and priorities. Changing how the organization of such work looks and acts is just the first step in the ongoing process of creating a reality that maximizes and celebrates diversity. The process requires a long-term commitment and understanding that there will be shared risks, responsibilities and rewards.

Successful cooperation should be based on mutual respect, appreciation of differences, trust, plan, great patience, determination to adopt new approaches and attract partners who are usually not involved, and, above all, set a common goal.

Intercultural cooperation adds to the challenge of overcoming the communication barriers of different cultures, ethnic heritage, values, traditions, language, history, self-awareness and racial relations. These barriers must be overcome for cooperation to be successful. Participants in effective multicultural cooperation should have a comprehensive leadership that understands and strives for diversity, while solving problems and conflicts along the way. If you focus on a common goal and equal strength for all participants, this type of cooperation and the unification of the work of senior schoolchildren will have a great chance of success.

After analyzing the above during the study, it is identified that the fundamental conditions for the formation of sociocultural competence are:

1) The personal characteristics of students, as well as their needs;

2) The attitude of the teacher and student towards the culture and language being studied;

3) The correct use of the potential of both students and the subject studied;

4) Stimulating the need for communication with the world of peers from abroad.

Список использованной литературы:

1 Беленкова, Н.М. Атабекова, А.А. Иноязычная коммуникативная компетенция как средство социальной адаптации будущего специалиста в вузе: результаты экспериментального обучения[Текст] // Высшее образование сегодня. - 2009. - № 8. - С. 63-67.

2 Common European framework of reference for languages: Learning, teaching, assessment / ed. by K. M. СИМВОЛНАУКИ ІSSN 2410-700Х № 12 / 2018. Iriskhanova. - M. : Moscow state linguistic University, 2005. - $247 p$.

3 Елизарова, Г. В. Культураиобучениеиностраннымязыкам. - СПб.: КАРО, 2005. - 352 c.

4 Кунанбаева С.С. «Теория и практика современного иноязычного образования». - Алматьл. 2010. - $201 \mathrm{c}$.

5 Banks J. Cultural Diversity and Education: Foundations, Curriculum and Teaching. - Boston: Allyn and Bacon. - 2001. - 360 p.

6 Firth, G., Elford, H., Leeming, C., \& Crabbe, M. 'Intensive Interaction as a Novel Approach in Social Care: Care Staff's Views on the Practice Change Process, in Journal of Applied Research in Intellectual Disabilities. - 2008. - P. 58-69. 
7 Moussetes, A. The absence of women's voices in Hofstede's Cultural Consequences: A postcolonial reading. Women in Management Review, 22. - 2007. - P. 443-445.

8 Abdel Latif Sellami, "Teaching Towards Cultural Awareness and Intercultural Competence: From What Through How to Why Culture is?", Paper presented at the annual meeting of teachers of English to speakers of other languages. Vancouver, BC, Canada. -2000. - $280 p$.

9 ЗабродинаИ.К. Методикаразвитиясоциокультурныхуменийстудентов. LAPLambertAcademicPublishing. - 2012. - 216 c.

10 Пахотина С. Формирование социокультурной компетенциии студентов. - М. - 2014. $140 \mathrm{c}$.

\section{References:}

1. Belenkova, N.M. Atabekova, A.A. Inoiazychnaia komunikativnaia kompetensia kak sredstvo sosiälnoi adaptasii buduşego spesialista v vuze: rezültaty eksperimentälnogo obuchenia[Teks] // Vysşee obrazovanie segodnä. - 2009. - № 8. - S. 63-67.

2. Common European framework of reference for languages: Learning, teaching, assessment / ed. by К. М. СИМВОЛНАУКИ ISSN 2410-700Х № 12 / 2018. Iriskhanova. - M. : Moscow state linguistic University, 2005. - $247 p$.

3. Elizarova, G. V. Külturaiobuchenieinostrannymäzykam. - SPb.: KARO, 2005. - 352 s.

4. Kunanbaeva S.S. «Teoria i praktika sovremennogo inoiazychnogo obrazovania». - Almaty. - 2010. $-201 s$.

5. Banks J. Cultural Diversity and Education: Foundations, Curriculum and Teaching. - Boston: Allyn and Bacon. - 2001. - 360 p.

6. Firth, G., Elford, H., Leeming, C., \& Crabbe, M. Intensive Interaction as a Novel Approach in Social Care: Care Staff's Views on the Practice Change Process, in Journal of Applied Research in Intellectual Disabilities. - 2008. - P. 58-69.

7. Moussetes, A. The absence of women's voices in Hofstede's Cultural Consequences: A postcolonial reading. Women in Management Review, 22. - 2007. - P. 443-445.

8. Abdel Latif Sellami, "Teaching Towards Cultural Awareness and Intercultural Competence: From What Through How to Why Culture is?", Paper presented at the annual meeting of teachers of English to speakers of other languages. Vancouver, BC, Canada. -2000. - $280 \mathrm{p}$.

9. Zabrodinaİ.K. $\quad$ Metodikarazvitiasosiokülturnyhumenistudentov. $\quad-\quad M .:$ LAPLambertAcademicPublishing. - 2012. - 216 s.

10.Pahotina S. Formirovanie sosiokülturnoi kompetensii studentov. - M. - 2014. - 140 s.

МРНТИ 16.21.23

https://doi.org/10.51889/2020-2.1728-7804.17

Косымова Г., ${ }^{1}$ Бурибаева Ж. ${ }^{2}$

1,2 Абай атындавы Қазақ ұлттық педагогикальққ университеті, Алматы, Қазақстан

\section{МАҚСАТ КАТЕГОРИЯСЫНЫН КАЗАҚ ТІЛ БІЛІМІНДЕГІ КӨРІНІСІ}

Аң̧датпа

Мақала қазақ тіл біліміндегі “мақсат категориясы” ұғымын ашуға арналған. Ең бірінші мақсат категориясына анықтама беріліп, оның түрлі салада қолдану ерекшеліктері сөз етілген. Аталған мәселеге қатысты отандық және шетелдік ғалымдар зерттеулері мен ұстаным - пікірлері басшылыққа алынған. Мақсат категориясын талдау барысындағы “адресант факторының” маңыздылығы айтылған. Сондай-ақ мақсат категориясын жүзеге асыру барысында қолданылатын әдіс-тәсілдер сөз етіледі. Сөйлеу актісінің түрлеріне талдау жасалынған. Аталған категорияның дискурстағы орны, өзіндік ерекшеліктері айшықталған.

Қазіргі таңда лингвистикада дискурс зерттеу ретінде маңызды орын алады. Жаһандану идеялары кейбір дискурстарды тікелей генерациялайды, бұл көбінесе зерттеушілердің назарынан тыс қалады, демек, дискурс - талдаудың эвристикалық мүмкіндіктерін төмендетуге алып келеді, ол тек мәтіндерді 